\title{
Soil Fertility Status of Mandal Block in Bhilwara District of Rajasthan, India
}

\author{
O.P. Gurjar*, Ramawatar Meena and Achin kumar and Surya Kant \\ Department of Soil Science and Agricultural Chemistry, Institute of Agricultural Sciences, \\ Banaras Hindu University, Varanasi 221005, UP, India \\ *Corresponding author
}

\begin{tabular}{l} 
K e y w o r d s \\
Soil fertility, \\
Available nutrients. \\
Article Info \\
$\begin{array}{l}\text { Accepted: } \\
17 \text { July } 2017 \\
\text { Available Online: } \\
10 \text { September } 2017\end{array}$ \\
\hline
\end{tabular}

Keywords

Soil fertility, Available nutrients.

Article Info

17 July 2017

10 September 2017

\section{A B S T R A C T}

A study was conducted from Mandal block in Bhilwara district of Rajasthan for assess the fertility status of cultivated land soils near and far away from industries area. Soil samples were taken from cultivated fields of 52 villages $(0-15 \mathrm{~cm}$ depth) and analyzed for their physico-chemical properties to prepare the map on the basis of nutrient status in the soil. The $\mathrm{pH}$ of soil samples were observed from neutral, slightly alkaline to strongly alkaline. The EC was safe range for cultivated land. Soil organic matter content (\%) was found in low to medium range. Available nitrogenwas low, phosphorus was low to medium, potassium was high, sulphur was low too high in range while in soils of Mandal block. Calcium and magnesium were sufficient in range of studied area.

\section{Introduction}

Soil is a component of the lithosphere and biosphere system. It is a vital natural resource on which the supporting life systems and socio-economic development depends. The crisis of land degradation is mainly related to increasing population pressure. The per capita cultivable land has been declined from 0.32 ha in 1950's through 0.14 by the turn of the Century to less than 0.1 ha by 2010 . In India the resources available for agriculture are narrow. Our aim of maximizing the utilization of land resources with intensive of agriculture resulted either in the fast loss of nutrients or occasionally in their fixation. It is therefore important to monitor the fertility status of soil from time to time with a view to justify the soil health. The intensively cultivated soil is usually deficient in macro. This study was carried out to find out nutrient status of area and the fertility constraints which hinder the growth of crops. Soil samples were collected and analyzed for various physico-chemical properties and mapping of studied area were developed according to the nutrient availability in soils of Mandal block.

\section{Materials and Methods}

The studied area selected from Bhilwara district in Mandal block. It's situated between latitude of $25^{\circ} 26^{\prime} 21.25^{\prime \prime} \mathrm{N}$ and a longitude of $74^{\circ} 35^{\prime} 3.86$ "E or 25.439235 and 74.584406 
respectively. The studied area comes under sub agro ecological Sub Region (ICAR) Northern Plain (And Central Highlands) Including Aravallis, Hot Semi-Arid EcoRegion Agro-Climatic Zone (Planning Commission) Central Plateau and Hills Region (VIII) Agro Climatic Zone (NARP) Sub Humid Southern Plain Zone (RJ-7) Bhilwara district has a dry climate due to low rainfall and arid region zone of Rajasthan (Table 1).

Its humid climate having mean annual temperature of more than 22 degree Celsius and average rainfall is $650 \mathrm{~mm}$. Soil samples of the cultivated land from different villages of Mandal block were taken randomly to a depth of $0-15 \mathrm{~cm}$ with the help of khurpi. The soil samples were mixed thoroughly and about 500 gram of composite soil samples were taken for analysis.

The processed soil samples were analyzed for different nutrients using specific standard procedures for primary and macro nutrients. Soil $\mathrm{pH}$ was determined by $\mathrm{pH}$ meter, EC by conductivity meter, bulk density and particle density by pycnometer, water holding capacity was measured by keen box.

The organic matter content was determined by Walkey and Black (1934) method, available nitrogen was estimated by alkaline $\mathrm{KMnO}_{4}$ method, available phosphorus was extracted by $0.5 \mathrm{M} \mathrm{NaHCO}_{3}$ solution $\mathrm{pH} 8.5$, and color developed by ascorbic acid method. Available potassium was determined by neutral normal ammonium acetate method, with the help of flame photometer. Sulfur was estimated by calcium chloride method. Exchangeable calcium and magnesium were analyzed by complexometric titration.

\section{Results and Discussion}

The analyzed data pertaining fertility status of Mandal block was presented in table 2.

\section{Physico-chemical properties of soil}

Out of the total soil samples, $28(16.37 \%)$ soil samples were neutral (6.5-7.5), 131 $(77.77 \%)$ soil samples were slightly alkaline (6.5 to 8.5) and $10(5.84 \%)$ soil samples were strongly alkaline (8.6 to 9.2) in reaction. The EC was varied from 0.25 to $2.2 \mathrm{dSm}^{-1}$ with an average value of $0.74 \mathrm{dSm}^{-1}$. Out of 171 soil samples to $115(67.25 \%)$ soil samples lie in safe range,55 samples $(32.16 \%)$ are normal range and one sample $(0.006 \%)$ is unsafe range so studies present in soil electrical conductivity no harm in germination of seed, as maximum number of sample. The bulk density and particle density ranges from 1.121.61 and $1.95-2.77 \mathrm{Mgm}^{-3}$ respectively with a mean of 1.36 and $2.51 \mathrm{Mgm}^{-3}$. Water holding capacity of soil ranges from 19.97 to $54.68 \%$, with a mean of $37.09 \%$. Porosity of soil ranges from 25.47 to $52.7 \%$, with a mean of $45.78 \%$. The data on per cent organic carbon content were ranges from 0.15 to 1.28 with a mean value of 0.50 . Out of 171 soil samples to $53.80 \%$ (92) samples were found low, $33.33 \%$ (57) samples were found Medium and $12.86 \%$ (22) samples were found high in organic carbon. Thus majority of the soil samples of Mandal block are low to medium and few samples were high in organic carbon per cent due to the arid area is responsible low organic matter and some area were high in OC percent due to use of every year FYM and crop residues. The similar results were also reported by Kumar and Seth (1983), Aggarwal and Kumar (1994), Prakash (2001), Meena et al., (2006) and Yadav and Meena (2009) and Dinesh Khadka et al., (2016) in Agriculture Research Station, Belachapi, Dhanusha, Nepal.

\section{Status of primary nutrients in soil}

The status of $\mathrm{N}, \mathrm{P}$ and $\mathrm{K}$ has been shown in table 2. Available $\mathrm{N}$ content of these soils were ranged from 110 to $412.89 \mathrm{~kg} \mathrm{ha}^{-1}$ with a mean value of $194.23 \mathrm{~kg} \mathrm{ha}^{-1}$. Out of 171 
soil samples to $163(95.23 \%)$ soil samples were found low, and $8(4.67 \%)$ samples were found in medium range. Climate has a major impact on availability of nitrogen, maximum soil samples were found in low category, it may be due to leaching and denitrification dry climate and use of low amount of bio fertilizers, green manures and use of nitrogenous fertilizers.

The available phosphorus content in these soils was varied from 6.61 to $31.88 \mathrm{Kg} \mathrm{ha}^{-1}$ with a mean value of $14.05 \mathrm{Kg} \mathrm{ha}^{-1}$. Total soil samples collected to $56(32.74 \%)$ soil samples were found low, $111(64.91 \%)$ soil samples were found medium and $4(2.33 \%)$ soil samples were high in Phosphorus content.

These results are strongly supported by the findings of Kumar and Seth (1983) who reported that the soil were medium in available phosphorus. Such findings were also reported by Singh and Sharma (1984), Akbari et al., (1993), Kamariya (1995), Ghosh \& Hasan (1976), Hasan (1996) in some soils of district of territories states and Meena et al., (2006).

The potassium content in these soils was ranged from 343.87 to $776.82 \mathrm{~kg} \mathrm{ha}^{-1}$ with an average value of $456.59 \mathrm{~kg} \mathrm{ha}^{-1} \mathrm{~K}$. All of 171 $(100 \%)$ soil samples were found high in Potassium content. This may be due to presence of potash bearing minerals (muscovite, biotite and feldspar).

As per criterion laid down by Muhr et al., (1965), maximum soils samples $72.72 \%$ were found under high category (above $300 \mathrm{~kg} \mathrm{~K}_{2} \mathrm{O}$ $\mathrm{ha}^{-1}$ ) of available potassium. Hence, it is found that all soils of the study area were high in available potassium. Such result was also reported by Prakash (2001) and Meena et al., (2006).

\section{Status of secondary nutrients in soil}

The data on status of available $S$ exchangeable $\mathrm{Ca}^{2+}$ and $\mathrm{Mg}^{2+}$ of soils of Mandal block of Bhilwara district were presented in table 2. The available sulphur content in soils of Mandal block was ranged from 3.71 to $46.2 \mathrm{~kg} \mathrm{ha}^{-1}$ with an average value of $16.81 \mathrm{~kg} \mathrm{ha}^{-1}$.

Out of total soil samples $19(11.11 \%)$ soil samples were found low, $108(63.15 \%)$ soil samples were found medium and $44(25.73 \%)$ soil samples were found high in sulphur content in soils of Mandal block.

Table.1 Characterization of soil test values for different nutrients

\begin{tabular}{|c|c|c|c|}
\hline \multirow[t]{2}{*}{ Nutrients } & \multicolumn{3}{|c|}{ Rating of the soil test values } \\
\hline & Low & Medium & High \\
\hline Organic (\%) & $<0.5$ & $0.5-0.75$ & $>0.75$ \\
\hline Available N $\left(\mathrm{kg} \mathrm{ha}^{-1}\right)$ & $<280$ & $280-560$ & $>560$ \\
\hline Available P $\left(\mathrm{kg} \mathrm{ha}^{-1}\right)$ & $<12.5$ & $12.5-25$ & $>25$ \\
\hline Available $\mathrm{K}\left(\mathrm{kg} \mathrm{ha}^{-1}\right)$ & $<135$ & $135-335$ & $>335$ \\
\hline \multirow[t]{2}{*}{ Available S $\left(\mathrm{kg} \mathrm{ha}^{-1}\right)$} & $<10$ & $10-20$ & \multirow{2}{*}{\begin{aligned} \multicolumn{1}{c}{$>20$} \\
Sufficient \end{aligned}} \\
\hline & \multicolumn{2}{|c|}{ Deficient } & \\
\hline $\begin{array}{l}\text { Calcium } \\
\left(\mathrm{Cmol}(\mathrm{P}+) \mathrm{kg}^{-1}\right)\end{array}$ & \multicolumn{2}{|c|}{$<1.5$} & $>1.5$ \\
\hline $\begin{array}{l}\text { Magnesium } \\
\left(\mathrm{Cmol}(\mathrm{P}+) \mathrm{kg}^{-1}\right)\end{array}$ & \multicolumn{2}{|c|}{$<1$} & $>1$ \\
\hline
\end{tabular}


Table.2 Soils properties of study area

\begin{tabular}{|c|c|c|c|c|}
\hline Soil Characteristics & Range & Mean & S.D. & C.V. (\%) \\
\hline pH (Soil:water,1:2.5) & $6.5-9.2$ & 8.04 & 0.5038 & 6.26 \\
\hline $\mathrm{EC}\left(\mathrm{dSm}^{-1}\right)$ & $0.25-2.2$ & 0.74 & 0.3675 & 9.26 \\
\hline B.D. $\left(\mathrm{Mg} \mathrm{m}^{-1}\right)$ & $1.95-2.77$ & 1.36 & 0.0913 & 6.71 \\
\hline P.D. $\left(\mathrm{Mg} \mathrm{m}^{-1}\right)$ & $1.95-2.77$ & 2.51 & 0.1785 & 7.09 \\
\hline W.H.C. (\%) & $19.97-54.68$ & 37.09 & 6.3002 & 16.98 \\
\hline Porosity (\%) & $25.47-52.70$ & 45.78 & 4.1990 & 9.17 \\
\hline O.C. $(\%)$ & $0.15-1.28$ & 0.50 & 0.2137 & 42.58 \\
\hline AvailableN $\left(\mathrm{kg} \mathrm{ha}^{-1}\right)$ & $110.82-412.89$ & 194.23 & 55.5494 & 28.59 \\
\hline Available P $\left(\mathrm{kg} \mathrm{ha}^{-1}\right)$ & $6.61-31.88$ & 14.05 & 4.0144 & 28.55 \\
\hline Available $\mathrm{K}\left(\mathrm{kg} \mathrm{ha}^{-1}\right)$ & $343.87-776.8$ & 456.59 & 55.7840 & 12.21 \\
\hline Available S $\left(\mathrm{kg} \mathrm{ha}^{-1}\right)$ & $3.71-46.20$ & 16.81 & 6.4809 & 38.53 \\
\hline Available $\mathrm{Ca}(\mathrm{Cmol}(\mathrm{P}+)(\mathrm{kg}-1)$ & $1.31-17.29$ & 6.88 & 3.0164 & 43.80 \\
\hline Available M (Cmol (P+) (kg-1) & $0.23-6.02$ & 2.47 & 1.2940 & 52.24 \\
\hline
\end{tabular}

Also the coarse-textured sandy soils generally have low total S-content as compared to fine textured soils (Kanwar, 1976) however he also had no opinion that sufficiency of available sulphur is directly proportional to the organic matter content of the soil. The similar results were found by Jat and Yadav (2006) in soils of Entisols of Jaipur District, Rajasthan and Singh and Singh (2007) in soils of mid-Western Uttar Pradesh.

The data revealed that the exchangeable $\mathrm{Ca}^{2+}$ content of these soils was ranges from 1.31 to $17.29 \mathrm{Cmol}\left(\mathrm{P}^{+}\right) \mathrm{kg}^{-1}$ with an average value of $6.88 \mathrm{Cmol}\left(\mathrm{P}^{+}\right) \mathrm{kg}^{-1}$. One soil sample was deficient and $170(99.47 \%)$ soil samples were found sufficient in available calcium. It may be due to use of calcium rich fertilizer or due to use of lime on the soil of studied area. The similar trend was also recorded by Nayak et al., (2006) in swell and shrink soils of Vertisol order in Vidarbha region and Tripathi and Sawarkar (2007) in soils Vertisolpedons of Kymore plateau in Jabalpur District.

The exchangeable $\mathrm{Mg}^{2+}$ content in soils of Mandal block were varied from 0.23 to 6.02 Cmol $\left(\mathrm{P}^{+}\right) \mathrm{Kg}^{-1}$ with a mean value of 2.47 $\mathrm{Cmol}\left(\mathrm{P}^{+}\right) \mathrm{kg}^{-1}$. Out of all soil samples to 18
(10.52\%) soil samples were found deficient, $153(89.47 \%)$ soil samples were found sufficient in available magnesium. The similar results were observed by Prasad et al., (2006) in swell-shrink orange cropped soils of Nagpur District and Nayak et al., (2006) in swell and shrink soils of bulk density.

It can be concluded that, the soil from Mandal block of Bhilwara district is categorized under neutral to alkaline and slightly saline in reaction, soluble salt content falls under safe range does not affect germination of crops. Organic carbon is low to medium range in the soils of studied area.

The soils under study areas are low in $\mathrm{N}, \mathrm{P}$ and $\mathrm{S}$ is medium while $\mathrm{K}$ was found in the soil high. Calcium and Magnesium also observed sufficient in soils of Mandal block. All areas shows similar values of B.D., P.D., and macronutrient except.

\section{References}

Aggarwal, R.K., and Kumar, P. 1994. Availability and management of nitrogen in soils of arid ecosystem. Annals of Arid Zone, 33: 1-18. 
Akbari, K.N., Karan, F. and Panday, H.R. 1993. Distribution of available $\mathrm{P}, \mathrm{K}$ and organic carbon in Mewar Region. Annals of Arid Zone, 32: 251-252.

Black, G.R., 1965. Particle density and bulk density. In C.A. Black (ed). Method of soil analysis part I. Am. Soc. Agron. Madison WI. Pp. 371-390.

Cheng, K.L., Bray RH 1951. Determination of magnesium and calcium in soil and plant material. Soil Sci72 : 44

Ghosh, A.B., and Hussan, R. 1976. Available potassium status of Indian soil. Bull. Indian Soc. Soil Sci., 12:1-18.

Hasan, R., 1996. Phosphorus status of soils in India. Better Crop International, 10(2): 4-5.

Jat, J.R., and B.L. Yadav, Different forms of sulphur and their relationship with properties of Entisols of Jaipur district (Rajasthan) under mustard cultivation. J. Indian Soc. Soil Sci., 2006, 54(2): 208-212.

Jatav, G.K., Mishra VN 2012. Evaluation of soil fertility status of available N, P \& K in inceptisol of Baloda block of Janigar district of Chhattisgarh. J ProgAgric3 : 28-32.

Khadka Dinesh, Lamichhane Sushil, Khan Shahabuddin, Joshi Sushila and Pant Buddhi Bahadur, 2016. Assessment of soil fertility status of Agriculture Research Station, Belachapi, Dhanusha, Nepal. Journal of Maize Research and Development, 2(1): 43-57
Meena, H.B., Sharma, R.P. and Rawat, U.S. 2006.Status of macro and micronutrients in some soils of Tonk district of Rajastan. J. Indian Soc. Soil Sci. 54(4): 508- 512.

Muhr, G. R., Datta, N. P., Sankara Subramoney, N., Dever, F., Lecy, V. K. and Donahue, R. R. 1965. Soil testing in India. USAID. Mission to India, New Delhi.

Nayak, A.K., Chinchmalatpure, R. Rao, G. Gururaja and A.K. Verma, Swell-shrink potential of vertisols in relation to clay content and exchangeable sodium under different Ionic Environment. J. Indian Soc. Soil Sci., 2006, 54(1): 1-5.

Olsen, S.R., Cole CV, Watanabe FS, Dean LA 1954. Estimation of available phosphorus in soil by extraction with sodium by carbonate. Circular US Dep of Agric : 1400 Independence Ave SW Washington DC. Pp. 939.

Walkley, A., and Black, I. A. 1934. An Examination of Degtjareff method for determining soil organic matter and a proposed modification of the chromic acid titration method. Soil Science, 37: 29-37.

Yadav, R.L., and Meena, M.C. 2009. Available micronutrient status and their relationship with soil properties of Degana soil series of Rajasthan. Journal of the Indian Society of Soil Science, 57: 90- 92.

\section{How to cite this article:}

Gurjar, O.P., Ramawatar Meena and Achin kumar and Surya Kant. 2017. Soil Fertility Status of Mandal Block in Bhilwara District of Rajasthan. Int.J.Curr.Microbiol.App.Sci. 6(9): 11541158. doi: https://doi.org/10.20546/ijcmas.2017.609.139 